DOI https://doi.org/10.30525/978-9934-26-000-1-6

\title{
МЕТОДИ ВИЯВЛЕННЯ АЛЬТЕРНАТИВНИХ КОМУНІКАЦІЙ
}

\author{
Мельникова-Курганова О. С. \\ кандидат наук із соціальних комунікаиій, \\ дочент кафедри сочіальних комунікацій \\ Маріупольський державний університет \\ м. Маріуполь, Донещька область, Украӥна
}

В суспільстві постправди 2.0. існує безліч правд та істин, які знаходять свою аудиторію. У безперервному потоці надлишкової інформації важко відрізнити факт, думку, фальшивий контент. Тому аудиторія шукає альтернативні канали чи платформи комунікації, альтернативний контент.

Альтернативна комунікація представляє власне альтернативу провідній/офіційній точці зору влади та засобів масової інформації. Вона може зустрічатися як в демократичному суспільстві, так і в тоталітарному, авторитарному. Альтернативна комунікація може бути властива опозиційним та протестним рухам, іiї контент відкрито спрямований проти офіційної позиції влади.

Специфіку альтернативних медіа досліджували Н.Чомскі, П. Бурдьє, Ю.Бондаренко, Г. Почепцов та ін.

Історичною основою для альтернативних медіа стали дисидентські комунікації, їх розглядаємо як соціальні комунікації, що мають інструментарій, способи, засоби, принципи та методи поширення альтернативних або заборонених офіційною владою інформації, знань та ідей за допомогою альтернативних, конспіративних каналів $[1$, c. 20]. Дисидентські комунікації були заборонені в закритому типі суспільства тоталітарної держави, оприлюднювали замовчувану або заборонену владою інформацію, нові знання та контрсмисли. На думку Ю. Бондаренко, «альтернативні медіа, які відмовилися від комунікації в одному напряму, надають можливість читачам самостійно створювати медіаконтент, спрямований на особливу цільову аудиторію - контргромадськість - представників різних соціальних груп та субкультурних угрупувань» [2, с. 16].

Н. Чомскі виділяв медіа за критеріями альтернативності 3MI: 1) форма власності; 2) джерела фінансування; 3) джерела інформації; 4) особлива форма лобізму; 5) ідеологія. Він зазначав, що медіа, які творять опір пропаганді, необхідні та ефективні [3].

П. Бурдьє вважає, що альтернативні ЗМІ здатні збалансувати провладні 3МI, однак не значною мірою. Він пропонує підхід до розробки соціології альтернативних засобів масової інформації [4]. 
На думку Г. Почепцова, «для СРСР знаковою стала фраза про кухонні розмови, яка підкреслювала невідповідність офіційного і неофіційного спілкування людей. Кухонні розмови були правдою, а газета ні. Саме кухня стала місцем вільного обміну думками» [5]. Отже, «кухонні розмови», організовані літературні вечори в квартирах, клубах творчої молоді мають риси групової комунікації, до речі, як і в закриті групи в соціальних мережах.

Основні методи виявлення альтернативних комунікацій пов'язані з ознаками: 1) альтернативний контент; 2) альтернативні канали; 3 ) альтернативні ідеї. В інформаційну епоху постправди 2.0. відмінними рисами $\epsilon$ велика кількість повідомлень та платформ їх розповсюдження в мережі Інтернет: «Ми отримали різноманітність інформаційних об'єктів, які особливо не помітні за ступенем достовірності. Але зате всі вони експлуатують фактор залучення уваги до себе, що стало особливо важливим в ситуації надлишку інформації» [6]. На платформі нових медіа, соціальних мереж з'явилися «інформаційні бульбашки», комфортне інформаційне середовище.

Разом із тим, позиції та думка в суспільстві поляризуються, споживач інформації вірить лише в свою «істину», не приймає «конфліктну» його поглядам повідомлення чи ідеї. Звичайно, проблему поглиблюють ботоферми з арміями тролів чи ельфів. Наразі постає проблема формування критичного мислення аудиторії.

Альтернативна комунікація більше залучає уваги аудиторії за допомогою повідомлень, інсайдерських джерел інформації, конспіративних методів іiі збору тощо. Крім того, альтернативний контент може формувати сумнів до офіційної точки зору влади, опосередковано спростовувати якісь факти або ідеї.

Модель гейткіпера/воротаря в теорії комунікації посідає значне місце. Зокрема відбір новин та формування порядку денного на каналі або медіаплатформі відрізняє альтернативний контент. Роль професійного альтернативного комунікатора $\epsilon$ значущою і ще неоціненною (наприклад, телеграм-канал «НЕХТА» в Білорусі).

Дисидентські комунікації в Україні характеризувалися повторною передачею повідомлень, редагуванням повідомлень різними особами, розповсюдження за допомогою неофіційних каналів як самвидав або тамвидав, радіо. Сучасні кросмедіа побудовані на різній подачі та незначній зміні контенту для конкретної платформи, мають рисиальтернативних комунікацій.

На думку Ф. Кайнд-Ковача та Д. Лабова альтернативні ідеї та контент циркулюють в Інтернеті і мають вплив на транснаціональні комунікації. «Сучасні стратегії альтернативних 3МІ та культури оцінюються у світлі останніх політичних умов» [7, с. 76]. Блогосфера $є$ продовженням дисидентських комунікацій та виступає як альтернативні медіа. Також з'явився електронний тамвидав, отримала розвиток альтерна- 
тивна культура в інтернеті, особливо у 2020 р. за карантинних умов (наприклад, проєкт «Ізоізоляція» у Facebook).

Біографічні наративи дисидентів цікавили аудиторію читачів як простір особистісних смислів в самвидаві. Сьогодні в українському інформаційному просторі історія політв'язня О. Сенцова, маріупольських моряків періодично викликає інтерес аудиторії, а саме до особистісних наративів. Правозахисна тематика $є$ актуальною і сьогодні, i за радянські часи. В мережі Інтернет можна побачити прямі включення 3 суду над політв'язнями. Популярні 1960-1980 pр. заборонені закордоні 3МI «Радіо Свобода», «Голос Америки» сьогодні пропонують свій контент як нові медіа.

Блогер як непрофесійний комунікатор та альтернативний лідер громадської думки формує власну онлайн-публіку. Автори альтернативних текстів надають іншого змісту інформації, інтерпретують реальну дійсність, протиставляючи офіційній позиції в державі. Крім того, за допомоги використання забороненої владою інформації вони привертають увагу до свої полемічних текстів. Характерними рисами також $\epsilon$ емоційно забарвлена лексика, риторичні фігури, концептуалізм та філософічність, засоби переконання, тому альтернативна комунікація набуває нового смислового наповнення.

Альтернативні комунікації розповсюджують ідеї альтернативної освіти в мережі Інтернет (вебінари, онлайн-тренінги та ін ший контент, який не представлено в традиційних закладах освіти). За традицією дисидентських комунікацій, альтернативні також $є$ платформою для електронних петицій, які підтверджуються електронними підписами. Але особливістю сьогодення, на нашу думку, є те, що офіційні представники влади використовують альтернативні канали, авторів, платформи, контент 3 метою досягнення якоїсь мети.

Таким чином, серед методів виявлення альтернативних комунікацій виокремимо пошук альтернативних контенту та ідей, альтернативних каналів та платформ комунікації; наявність альтернативних авторів, блогерів та гейткіперів «стрічки новин»; наративність, полемічність матеріалів; використання контрсмислів чи контрагрументів офіційній комунікації; визначення правозахисної тематики як провідної.

\section{Література:}

1. Мельникова-Курганова О.С. Особливості дисидентських комунікацій в Україні 1960 - початку 1990 рр.: монографія. Маріуполь: ТОВ «ПНС», 2020. 228 c.

2. Бондаренко Ю. Альтернативна преса сучасної Німеччини (особливості функціонування, редакційна політика, місце в національнійсистемі медіа): автореф. дис. канд. наук з соц. комунікацій: 27.00.04. Львів: Львів. нац. ун-т ім. І. Франка [б. в.], 2017. 20 с. 
3. Chomsky N. Necessary Illusions: Thought Control In Democratic Societies. URL: https://archive.org/stream/media_Noam_Chomsky-Necessary_Illusions/Noam_Chomsky-Necessary_Illusions_djvu.txt (дата звернення: 01.11.2020).

4. Бурдье П. Социология социального пространства. URL: http:// bourdieu.name/content/burde-sociologija-socialnogo-prostranstva (дата звернення: 01.11.2020).

5. Почепцов Г. Холодна війна - i вчора і сьогодні - як системний обмін комунікативними ударами. URL: http://www.telekritika.ua/ daidzhest/2011-08-12/64981(дата звернення: 01.11.2020) .

6. Почепцов Г. Пропаганда и фейки в систематике операций влияния. URL: https://ms.detector.media/mediaanalitika/post/22821/2019-05-05propaganda-i-feiki-v-sistematike-operatsii-vliyaniya/ (дата звернення: 01.11.2020).

7. Kind-Kovács F., Labov J. Samizdat, Tamizdat, and Beyond: Transnational Media During and After Socialism. Berghahn Books, 2015. 380 p. 